\title{
The relationship between the countries' performances at the major sport events with their performance at the Olympic Games
}

\author{
Shahab BAHRAMI, Bahman ASGARI \\ Department of Physical Education and Sport Science, Kermanshah Branch, Islamic Azad University, Kermanshah, Iran. \\ Address Correspondence to B. Asgari, bahman.asgari@yahoo.com.
}

\begin{abstract}
The purpose of this study was study of Relationship between countries performance at multi-sport events and world championships with their performance at Olympic Game. The population of all the countries in the Olympic Games medals have been won that their number is equal 1166 (excluding repeat). Based on Morgan table, samples were selected equal 321. Information was collected from multiple sites such as international federations, Olympic Continental Councils and international Olympic committee. Also, for analyzing used descriptive and inferential statistics (Kolmogorov-Smirnov test and Spearman correlation coefficient) by SPSS software and significant level $\mathrm{p} \leq 0.05$. The results showed that there is positive and significantly relationship between the number of medals of gold, silver, bronze and total medals won by countries at former Olympic Games, world championships, Asian and Pan-American Games with the number of Medals of gold, silver, bronze and total medals won at upcoming Olympic Games, However, there is not significantly relationship between the number of medals of gold, silver, bronze and total medals won at all-African Games with the number of medals of gold, silver, bronze and total medals won at Olympic Games.
\end{abstract}

Keywords: Olympic Games, sport performance, multi-sport events, received medals, world championships.

\section{INTRODUCTION}

Forecast in sports is one of the topics that are considered by researchers of physical education and sport science. Also, media and experts of different nations to study the performance of athletes of their own country before sport events and Forecast the number of medals or rank of their country at upcoming events according, regard to all the circumstances. However, these Forecasts not have scientific aspect and just done regard to the performance analysis of their own country athletes and comparison with competitors. Several studies in the field of sport have reported more accurate forecasts by statistical models compared to the subjective judgment of experts $(4,6)$. Sport researchers used of several methods for forecasting the athletes' performance in various sports including football, tennis, basketball and professional league competitions, collegiate tournament and national, continental and world championships $(3,7,8,11,14$, 15).

The methods which used by researches for ranking athletes and sports teams are including of rank, medals, wins and losses, goals and etc. However, the level of athletes and sports teams have been assess in these studies and sport teams' performance of different countries and their ranking in several multi-sport events hasn't been analyzed. In several multi-sport events such as Olympic, it just can use rank and medals because of different sports with their own evaluation systems and these two indicators are common in all sports. Olympic Games are the biggest sport events in the world, undoubtedly. These games have become a place to gather and engage fans, athletes, coaches, supervisors, reporters, photographers, and most media and seen through live broadcasts in many TV channels. Also, many people pay special attention to this game, so that during the 1996 Atlanta Olympic which done for Centennial Olympic Games, approximately 3.5 billion viewers watched biggest sport event in the world during the sixteen days (13). Many researchers conduct for research on various aspects of the Olympic Games according to large number of spectators.

Forecast of different countries performance in the Olympic Games is one of the aspects that researchers have been investigating. For example, Mohammadi (12) presented mathematical model to rank the countries which participate in the Asian Games 2006. In this research, have been used of an 
alternative approach in ranking which try to remedied defect of common approach by refer to the ability of each country to win a medal. In this model, efficiency of each country is calculated by the number of gold, silver and bronze medals as the output and considering indicators such as GDP, population, infant mortality rate, life expectancy and Gini coefficient as input that efficiency rates the criterion for ranking countries. The results showed that the ranking in this method is more equitable than the current method of ranking in Asian Games. Moreover, in this study the rankings of countries based on gold medals has been criticism and refer to total medals rating as more appropriate ranking. In research as prediction of countries performance in Asian Games using a neural network model; Hemati Nejad et al. (10) reported that there is significant and strong relationship between their forecast for countries performance at Asian games 2010 and actual performance $(\mathrm{r}=0.86)$. The this study is reported first to fifth rank in the 2010 Guangzhou Asian Games will accrue to China, South Korea, India, Iran, Japan and Kazakhstan (Iran and Japan will get forth rank jointly). In this forecast, all of places were correctly predicted except place of India and Japan.

Forrest et al. (5) predicted Medals of the National teams participated in 2008 Beijing Summer Olympic. In this study was used a statistical model based on the descent analysis of the number of medals at the previous period of Olympic Game and GDP. In the current study, the final predictions about major changes in the distribution of medals compare to the 2004 games, particularly increases medals for China and the UK and decrease of Russia's medals was correct. Also, Condon et al. (2) by neural network, was forecasted success in 1996 Olympic Games. In this study data of 271 sports from 195 countries on 17 independent variables were collected and concluded to predict the success of countries in the Olympic Games, the neural network model is a more appropriate tool than the regression model. Furthermore, Kuper \& Esterken (9) forecast the number of medals for all of countries participated at 2012 London Olympic by a mathematical model and variables such as GDP, population, distance to the Games place, performance in world championships and etc. Results showed that China, America, Russia and Great Britain will be introduced as the top four countries in the 2012 London Olympics. One positive aspect of this study is using of the number of medals won in homogeneous events which in the present study is considered by researchers.

As be seen, macro variables used to forecasting the Olympics results while according to research by Bernard and Bass (1) the importance of macro-level factors in forecasting the countries' performance at the Olympics has decreased in the past two decades. So, it seems that countries' performance at the Olympics with their performance at the past sport events can be more precise and more tangible. Therefore in this study, it is focus on the previous sport events such as world championships, Olympic Games and Continental Games as prediction and homogeneous variables for forecasting the Olympic Games results. However, according to planning of some countries in sport and improve or decline their performance as well as economic, political and etc crises, we not only judgment based on the performance in late years, but also must rely on recent periods or the corresponding events. Therefore in this study, will examined the relationship between the countries' performance (number of Medals of gold, silver, bronze and total medals won) in world championships, Olympic Games and Continental Games which been held before each Olympic and is between two consecutive Olympic with performance at upcoming Olympic Games. For example, relationship between countries' performance in world Championships from 2009 to 2012 (depending on the type of sport that held every year, two years or four years), Olympic Games (2008 Olympic Games) and Continental Games (been held at between 2009 to 2012) with their performance at the 2012 London Olympic Games are examined. So, this study tries to examine relationship between the countries' performances at previous sport events with their performances at the Olympic Games.

\section{MATERIAL \& METHODS}

Research method is descriptive and correlation. Research population was all the countries in the Olympic Games (from 1896 to 2012) which won medals and placed in final rankings which were 1166 countries (excluding repeaters). According to Morgan table, the fewer than 291 cases for 1161 are sufficient. According to access to information related to sport events medals in different sports in past years are not allowed, the available sampling was used and just countries which have been won medals in four previous Olympic and were 325 is selected as a sample. However, because of four countries (Australia, Greece, China and the UK) were as host in four Olympic, their information omit 
from the study about period that they were hosted and 321 samples were analyzed which it is more than the required samples. All of data was collected from different sites of International Federations, International Olympic Committee and Olympic continental Councils. In this study, descriptive and inferential indicator (Kolmogorov-Smirnov test and Spearman correlation coefficient) by SPSS software at a significance level $\mathrm{P} \leq 0.01$ was used.

\section{RESULTS}

The results of table 1 indicate that there is positive and significantly relationship between the number of Medals of gold, silver, bronze and total medals won by world countries at world championships with number of Medals of gold, silver, bronze and total medals won at upcoming Olympic Games.

The results of table 2 showed that there is positive and significantly relationship between the number of Medals of gold, silver, bronze and total medals won by world countries at former Olympic Games with the number of Medals of gold, silver, bronze and total medals won at upcoming Olympic Games.

Table 1. The relationship between the countries' performances at world championships with their performance at upcoming Olympic Games.

\begin{tabular}{lccc}
\hline & $\begin{array}{c}\text { Gold Medal of } \\
\text { Olympic Games }\end{array}$ & $\begin{array}{c}\text { Silver Medal of } \\
\text { Olympic Games }\end{array}$ & $\begin{array}{c}\text { Bronze Medal of } \\
\text { Olympic Games }\end{array}$ \\
\hline Gold Medal of world championships & $0.819^{*}$ & $0.688^{*}$ & $0.7011^{*}$ \\
Silver Medal of world championships & $0.730^{*}$ & $0.786^{*}$ & $0.679 *$ \\
Bronze Medal of world championships & $0.740^{*}$ & $0.717^{*}$ & $0.773^{*}$ \\
total medals of world championships & $0.805^{*}$ & $0.777^{*}$ & $0.754^{*}$ \\
\hline
\end{tabular}

* $\mathrm{P} \leq 0.01$

Table 2. The relationship between the countries' performances at former Olympic Games with their performance at upcoming Olympic Games.

\begin{tabular}{lccc}
\hline & $\begin{array}{c}\text { Gold Medal of } \\
\text { Olympic Games }\end{array}$ & $\begin{array}{c}\text { Silver Medal of } \\
\text { Olympic Games }\end{array}$ & $\begin{array}{c}\text { Bronze Medal of } \\
\text { Olympic Games }\end{array}$ \\
\hline Gold Medal of former Olympic Games & $0.703^{*}$ & $0.734^{*}$ & $0.680 *$ \\
Silver Medal of former Olympic Games & $0.721^{*}$ & $0.706^{*}$ & $0.695 *$ \\
Bronze Medal former Olympic Games & $0.703 *$ & $0.707^{*}$ & $0.663 *$ \\
total medals of former Olympic Games & $0.780 *$ & $0.785^{*}$ & $0.742 *$ \\
\end{tabular}

${ }^{*} \mathrm{P} \leq 0.01$

Table 3. The relationship between the Countries' Performances at continental Games with their performance at upcoming Olympic Games.

\begin{tabular}{|c|c|c|c|c|}
\hline & $\begin{array}{c}\text { Gold Medal of } \\
\text { Olympic Games }\end{array}$ & $\begin{array}{l}\text { Silver Medal of } \\
\text { Olympic Games }\end{array}$ & $\begin{array}{l}\text { Bronze Medal of } \\
\text { Olympic Games }\end{array}$ & $\begin{array}{l}\text { total medals of } \\
\text { Olympic Games }\end{array}$ \\
\hline Gold Medal of Asian Games & $0.721 *$ & $0.665^{*}$ & $0.651 *$ & $0.781 *$ \\
\hline Silver Medal of Asian Games & $0.727 *$ & $0.653 *$ & $0.645 *$ & $0.767 *$ \\
\hline Bronze Medal Asian Games & 0.695 * & $0.652 *$ & $0.660 *$ & $0.776^{*}$ \\
\hline total medals of Asian Games & $0.729 *$ & 0.674 * & $0.667 *$ & 0.796 * \\
\hline Gold Medal of Pan-American Games & $0.600 *$ & $0.659 *$ & $0.718^{*}$ & 0.736 * \\
\hline Silver Medal of Pan-American Games & $0.632 *$ & $0.626^{*}$ & $0.712 *$ & $0.730 *$ \\
\hline Bronze Medal Pan-American Games & 0.566 * & $0.605 *$ & $0.698 *$ & $0.702 *$ \\
\hline total medals of Pan-American Games & $0.617^{*}$ & $0.648 *$ & $0.720 *$ & $0.741 *$ \\
\hline Gold Medal of all-African Games & -0.226 & 0.141 & 0.244 & 0.125 \\
\hline Silver Medal of all-African Games & -0.262 & 0.126 & 0.249 & 0.095 \\
\hline Bronze Medal all-African Games & -0.281 & -0.073 & 0.147 & -0.048 \\
\hline total medals of all-African Games & -0.278 & 0.038 & 0.211 & 0.035 \\
\hline
\end{tabular}

${ }^{*} \mathrm{P} \leq 0.01$

Also, the results of table 3 showed that there is positive and significantly relationship between the number of medals of gold, silver, bronze and total medals won at Asian and Pan-American Games 
with the number of medals of gold, silver, bronze and total medals won at upcoming Olympic Games. However, there is not significantly relationship between the number of medals of gold, silver, bronze and total medals won at all-African Games with the number of medals of gold, silver, bronze and total medals won at upcoming Olympic Games.

\section{DISCUSSION}

The results show there is positive and significantly relationship between the number of Medals of gold, silver, bronze and total medals won by world countries at world championships with number of Medals of gold, silver, bronze and total medals won at upcoming Olympic Games. This show that if total medals in the World Championships (or gold, silver and bronze medals) increase or decrease for a country, total medals in Olympics (or gold, silver and bronze medals) will increase or decrease too and promote or fall in performance on World Championships before Olympics, countries' rank in Olympics will raise or fall. But some people believe that some of the countries don't use of all power in World Championships and use from all the powers in Olympic games which is important event. So, results show this topic does not certainty and there is strong correlation between Olympics and World Championships. Our findings are consistent with kuper and Esterken (2012) who refer to World Championships as predictor variable for Olympic Games.

Results show there is significance and strong correlation between number of medals (gold, silver and bronze medals) and total of earned medals at previous Olympics and number of medals (gold, silver and bronze) with total of won medals in next Olympics. It show the performance of each country in the Olympics is somehow related to its performance in the previous Olympic. Many analysts and experts to predict the number of medals at the Olympic don't attend to performance of their country in the previous Olympics. Although in recent years many changes have been seen in the Olympic Games rankings and some countries fall or rise tens of places in ranking table, we should not forget that this is only exceptions and advances and retreats in sport level, if there is no crisis, has been slow to happen at the national level. It can clearly be seen in the country place (2008 Beijing Olympic Games and the 2012 Olympic Games). That is we can see names of US, china, Russia, Great Britain, Germany, South Korea, France and Italy in the single-digit place on top of table in each periods and even previous periods. However, there are exceptions for example, the 34-step progress for Iran in London Olympics compared on Beijing Olympics. It is worth noting that the changes seen in the top of the table may be less than end of table because on top of table, the countries apart together based on the number of gold medals (e.g. US with 46 gold medals, China 38 and Great Britain with 29 gold medals have been the first to third place in London Olympic Games) while, at the end of table, just with one gold medal can be placed in higher place (e.g. Tajikistan placed in ranking 79 by one bronze medal in London Olympics and if won a gold medal, it could be placed in ranking 49).

Also, results show there is positive and significant correlation between number of gold, silver and bronze medals and total medals at Asian Games and Pan American Games with number of gold, silver and bronze medals and total medals in Olympic Games. It show that if the number of gold, silver and bronze medals an Asian country be higher (or American countries at Pan American Games), in compare of previous periods, in next periods will obtained more gold, silver and bronze medals and total medals. This is consistence with kuper and Esterken (2012). Hence, in current research, relation between number of medals in world championships in Olympic Games with the number of medals in Olympics were considered and such as our research it refer to an event which is homogeneous with Olympic Games (world championships) as event which performance on it relate to Olympic Games performance. However, Cooper \& Esterken (2012) used of two index i.e. the number of gold medals and total medals also in this study we use either two index or the number of silver and bronze medals. In general, it seem Asian games and Pan American Games have high quality and quantity level and if a country have good performance in these Games, will obtain to high results in Olympic Games while this is not correct about "All African Games". As we can see from results, there is not significance correlation between the number of gold, silver, bronze and total medals in All-African games with number of gold, silver, bronze and total medals in Olympic Games. This could be seen because there is mismatch between the quality and quantity of the Olympic Games and All African Games. If condition in two events has been same, performance of a country in both of them will be correlate and proportionate. For example, if the number of sports, condition of event implementation, competitor countries and etc, have 
been same into All-African Games and Olympic Games, there will positive and significance correlation between performance of a country in both events, while this correlation not exist about All-African Games. However, there is correlation between Asian and Pan American Games and show their condition is more same to Olympic Games and Asian and American countries can uses of these two events as equal event by Olympic Games. Even these events can used for Asian and American countries as preparation games for more readiness in the most sport event i.e. Olympic Games.

At the end, we can argue that instead of great variables for prediction of countries performance in Olympic Games, they can used of same level sport event such as multi-sport events (Olympic games, Asian and Pan American games and world Championships) and based on, sport performance expects will be reasonable. However, we should attend to significant variables for progression and recession in countries performance in Olympic Games. Finally, it recommended instead of solely using of macro indicators such as population, GDP, political and economic situation as effective variables on countries' performance at Olympic Games, researchers and specialists in physical education use homogeneous index in the World Championships, Continental Games and the performance on previous Olympic Games for studying possible performance in the upcoming Olympics Games which will forecast by macro variables. Furthermore, it can be argued that sports experts can extrapolate their countries athletes' performance at the all of major sport events to determine their situation at the Olympics Games and based on, studying and forecasting performance in the Olympic Games. Although the performance of athletes in various sport events such as hosting, draw, psychological conditions and damage might be changed to negative or positive, since in this study overall teams performance is criteria, failure to achieve the expected result by one of the athletes can't affect the overall performance of teams and may be other athletes have been higher performance and actually these weaknesses and strengths cover another.

\section{ACKNOWLEDGE}

This study is extracted from a research project that was sponsored by Islamic Azad University, Kermanshah branch. At the end, thank to the all supports for this research implementation by this university.

\section{REFERENCES}

1. Bernard A, Busse M.. Who wins the Olympic Games? Economic resources and medal totals. Rev Econ Stat, 2004; 86(1): 413- 417.

2. Condon EM, Bruce LG, Wasil EA. Predicting the success of nations at the Summer Olympics using neural networks. Comp Oper Res, 1999; 26: 1243-1265.

3. Corral JD, Rodriguez JP. Are differences in ranks good predictors for Grand Slam?. Int J Forecasting, 2010; 26: 551563.

4. Forrest D, Goddard J, Simmons R. Odds-setters as forecasters: The case of English football. Int J Forecasting, 2005; 21: 551564.

5. Forrest D, Ismael S, Tena JD. Forecasting national team medal totals at the Summer Olympic Games. Int J Forecasting, 2010; 26: 576-588.

6. Forrest D, Simmons R. Forecasting sport: the behaviour and performance of football Tipsters. Int J Forecasting, 2000; 16: 317-331

7. Goddard J. Regression models for forecasting goals and match results in association football. Int J Forecasting, 2010; 21: $331-340$.

8. Grant A, Johnstone D. Finding profitable forecast combinations using probability scoring rules. Int J Forecasting, 2010; 26: 498-510.

9. Kuper GH, Sterken E. Participation and Performance at the London 2012 Olympics. University of Groningen, 2012, www.rug.nl/feb.

10. Hematinezhad M, Gholizadeh MH, Ramezaniyan MR, Shafiee SH, Ghazi Zahedi A. Predicting the success of nations in Asian games using neural network. Sport Sci Pract Asp, 2010; 8(1): 33-42.

11. McHale I, Morton A. A Bradley-Terry type model for forecasting tennis match results. Int J Forecasting, 2011; 27(2): 619- 630 .

12. Mohammadi A. Mathematical models for ranking countries participating in the 2006 Asian Games. Olympic, 2010; (51): 719.

13. Sajadi N. Analysis of mass media role in the Olympics during the twentieth century. Harekat, 2009; (3): 39-56.

14. Stanula A, Maszczyk A, Roczniok R, Pietraszewski P, Ostrowski A, Zając A, Strzała M. The Development and Prediction of Athletic Performance in Freestyle Swimming. Journal of Human Kinetics, 2012; 32(1): 97-107.

15. Strumbelj E, Vracar P. Simulating a basketball match with a homogeneous Markov model and forecasting the outcome. Int J Forecasting, 2012; 28(2): 532-542. 